Boliak T. M. Professional competence of a primary school teacher as a condition for successful learning in a New Ukrainian School (NUS)

The articles consider the understanding and content of modern scientific and pedagogical terminology (reform of primary education, competence, pedagogical competence, professional competence, professional competence of primary school teachers) and "roles" of primary school teachers (facilitator, tutor), which appeared in the concepts of implementation New Ukrainian School (NUS); Emphasis is placed on the content of professional competence of primary school teachers and highlights the main components that are extremely important at the present stage of development of society, taking into account the changes taking place in education; Also, the theoretical analysis of psychological and pedagogical scientific literature allowed to identify five main criteria of professional competence of primary school teachers (general cultural criterion, general professional criterion, communicative criterion, personal criterion, criterion of development and self-education); According to the analysis of scientific works, the key components of a teacher's professional competence were identified and described, namely: informational, communicative, productive, moral, psychological, social, mathematical, autonomy for the competence and personal qualities of a teacher.

Emphasis is placed on the importance as a vector of humane and creative approach to primary school students of partnership pedagogy (students and their parents, culture of communication, interaction and cooperation between teachers). It is the pedagogy of partnership that allows individuals to successfully build relationships with other people, because without interaction with others, without understanding their own and their feelings, it is impossible to achieve common goals.

The professional competence of a primary school teacher is the result of creative professional activity, an integrated indicator of the personal activity essence of a teacher. A professionally competent teacher successfully solves the problems of the educational process, prepares students for life, achieves the desired results in personal development.

It is proved that a primary school teacher is the main actor in reforming the concept of the New Ukrainian School (NUS).

Key words: competence, pedagogical competence of teacher, professional competence of primary school teacher, New Ukrainian school, tutor and facilitator, pedagogy of partnership, primary education reform, primary school teacher.

\author{
UDC 37.091.2.041:78 \\ DOI https://doi.org/10.31392/NPU-nc.series5.2021.79.1.12
}

Bukhniieva O. A., Bankul L. D.

\title{
IMPLEMENTATION OF SELF-ORGANIZED EDUCATIONAL SPACE INTO THE PROCESS OF MUSIC ART LEARNING
}

The article is devoted to the consideration of the creation of a self-organized educational space in the field of music art. Also it is devoted to the peculiarities of its introduction into the modern system of education in educational institutions. This process is accompanied by significant innovative changes in pedagogical theory and practice, including music. The article states that one of the strategic directions in the education modernization is the transition to a new educational paradigm that provides cognitive activity and independent thinking of students. It is emphasized that in the conditions of rapid development of digital educational technologies has increased attention to subjects of training, their needs, interests, abilities. It demands rethinking of the organization of educational and pedagogical processes, methods and means, and also the maintenance of education. It is proved the innovativeness of creating a music art self-organized educational space. Due to this, there is a rethinking of the goals, content and objectives of education, as well as updating the training of future teachers of music art. It is established that self-organizing educational learning space gives students the opportunity to expand their horizons, worldview, improve their behavior. This space teaches to take responsibility for group work, to cultivate a sense of imaginary and moral maturity. It is defined the role of a teacher-facilitator who creates a creative favorable atmosphere to support the work of students. It is proved that as a result of the introduction of self-organized educational learning space a safe micro-environment is created for students. Students get a positive experience of music art learning in such environment. It is determined that the traditional system of education, existing in most educational institutions, has limited opportunities for self-development, as it is normative. Changing this system is a process that requires large resources and time. In the open educational space, the transition from normative to open self-organized learning allows the most effective use of the full synergetic approach as a basis for the formation of open ways of musical and cognitive activities, the search for adequate creative methods and technologies of music education.

Key words: self-organized educational space, self-development, openness of the education system, facilitator, innovative changes, musical art.

\section{(статтю подано мовою орихіналу)}

One of the key reforms in Ukraine in recent years is the reform of modern education and science. State policy in the field of education and science plays a crucial role in ensuring the development of human's capital and economic and spiritual cultural growth of society and youth. It is obvious that today Ukrainian education does not sufficiently meet the modern demands of the formation of personality, society and world trends. That is why a systematic transformation of the sphere is needed to ensure the latest modern quality of education at all levels.

Educational reform is carried out in such priority areas as the new Ukrainian school, affordable and high-quality secondary education, modern vocational education, quality higher education, development of science and innova- 
tion. Each of them implements tasks aimed at achieving a common goal: to transform modern Ukrainian education into an innovative environment where students acquire key competencies necessary for every modern person to succeed. And scientists have the ability and resources to conduct innovative research that influences and relates to the educational and cultural progress of the Ukrainian nation.

One of the important tasks defined in the Law of Ukraine "About Higher Education" is the formation of a person who is able to think independently and to self-organize. Modern demands declared in state educational documents create the basis for the formation and development of professional competencies of future teachers of the new Ukrainian school. In particular music teachers, among which the leading is the ability to self-organize their own educational space [11].

The general provisions of professional training and self-organization of future music art teachers were considered by the following scientists V. Antonyuk [1], N. Grebenyuk, D. Yevtushenko [4], V. Morozov [7], G. Panchenko [8], L. Totska, V. Ivanov, B. Gnyd [3], L. Prokhorova, O. Vasylenko [2], L. Manzhons [6], O. Pryadko [10] and others.

Among the methodological developments, the works of the following scientists reflect the possibilities of using the Internet for students to master civic and social competencies, which are the basis for the formation of independence in learning and life - L. Koretska, I. Nosach, L. Petushkova [5], L. Babenko, I. Hnativ, N. Lonshchakova, Y. Milenina, L. Romanova, T. Pecherskykh [9].

The training of modern specialists of the new generation encourages changes in the educational activities of future music art teachers. As a result, there is a rethinking of the goals, content and objectives of learning.

A teacher-specialist is a person who has a system of creative active thinking, professional mobility and adaptability, a high level of personal self-development. This person is capable of introducing into modern learning selforganized educational space. The modern school is a model of modern society in which students have the opportunity to learn to interact, coexist with other members of the educational environment, to gain a positive experience of self-organization, which can be reproduced in other social conditions.

The experiments of the Indian professor Sugata Mitra attracted public attention to the potential of self-organized learning. In 1999, on the outskirts of the Delhi capital, where most children did not attend school, a professor installed a computer with Internet access. In a few hours, local children learned to use it and search for information. Further actions confirmed the scientist's opinion that groups of children who have access to the Internet can learn independently. Children can independently learn even the basics of molecular biology, in addition, without knowledge of English. Based on these studies, Professor Sugata Mitra developed the concept of a self-organized educational space that describes the optimal conditions under which children can learn by collaborating with each other in traditional school settings.

In December 2013, the first laboratory of self-organized educational space was opened in a high school in Killingworth (UK). Seven more laboratories were later opened in India, the United Kingdom and the United States. The purpose of these laboratories is to provide an environment in which the global teacher community can study the impact of self-organized learning on children.

In 2014, it was launched the digital platform "School in the Cloud". This platform provides an opportunity to experiment with self-organized learning. Testing and assessment of the self-organized educational space methodology took place for thirteen years. Nowadays, this technology is used in educational institutions in different countries. In Ukraine, the first self-organized educational space was opened in the spring in 2017 in the city of Izmail, Odessa region under the auspices of Caritas-Odessa in partnership with Izmail State Humanitarian University and the charity "Free Education".

It should be noted that the educational space is a space filled not only with subject classes, but also a specially created cultural and educational environment. Such environment that is provided for the development of each child abilities and talents.

School age is precisely the period of child development during which insufficiently conscious and controlled mental processes are transformed into a developed, conscious and purposeful activity. At school age, the competent organization of the child's activities is possible only if its goals are close to the student and are intrinsically related to the content of the activity itself. It is not enough for a student to keep in mind only the distant end result of his activity, he needs the immediate goals that directly follow from his activity.

Closed educational space does not allow to effectively organize the pupil or student's personal development as a future teacher of music. This space complicates the exchange of musical and aesthetic values between generations, does not create situations for comparing opinions, assessments that contribute to the value of relationships. The traditional system of education, existing in most educational institutions, has limited opportunities for self-development, as it is normative, set "from above". Changing this system is a process that requires large resources and time. In the open educational space, the transition from normative to open learning makes it possible to more effectively use the full synergetic approach as a basis for the formation of open ways of musical and cognitive activities. It is the basis for the formation of the search for adequate creative methods and technologies of education.

In this context, the basic needs and opportunities of musical development are especially important. These needs provide students with a person-centered creative environment. This is an opportunity for aesthetic pleasure and selfdevelopment: physiological needs; the needs of group norms and ideals; needs for love, respect, recognition, public approval; work needs, significant creative activity; needs to maintain and increase self-esteem; cognitive needs in 
a special musical sphere of interests; needs for transformational activities; needs in the aesthetic design of the environment; needs for self-organization of the individual picture of the world; the need to master a higher level of skill; needs for self-actualization of the individual. Creating such a space requires changes in goal setting, the content of education, teaching and education methods, relationship styles, living conditions, management system.

The new generation requirements imply an active role of all participants in the educational process in the formation of a musically competent personality; ensuring the transition in education from a simple retransmission of knowledge to the development of creative abilities of students, the disclosure of their own capabilities, involving the preparation and implementation of development programs for students of universal learning activities.

Educational learning space is a world of activity and a world of ideas, imagination, cultural meanings and signs. It contains many ideas, concepts, scientific knowledge and human values, experiences, emotions. The individual is "immersed" in this world, making his personal choice. This is especially true of the potential of the world of music [9].

The educational space in an educational institution is adapted to solve educational problems. It exists within the musical and pedagogical reality due to the activities that are specially organized by adults together with students. These activities serve the aesthetic and cultural development of children. Active educational space is great because it provides each student with a choice of different types of musical and artistic activities (educational (theoretical disciplines), artistic (perception of a musical work, creation of a musical work), performing (vocal and choral singing, instrumental performance, etc.).

The transformation of the real environment into a single educational space is possible only in a purposeful way. The main feature of the single educational space of music education is that the educational and upbringing processes are integrated and interconnected.

The task of a music teacher is to make the most of the educational opportunities of a single educational environment and space where the educational institution operates; link knowledge with the creative interests of the individual; to help the child to take an active position in the team and to enrich the educational process with emotionally and aesthetically colored events; to provide socially useful orientation to his individual hobbies, creative abilities and needs; to organize joint musical and aesthetic activities of children and adults; to cause positive changes in the minds of students, which are manifested in emotional reactions, behavior, activities.

It is necessary to form a single educational space in terms of diversity of educational systems and types of educational institutions to achieve the main result - knowledge of the world. Also its aim is an effective implementation and mastering of educational programs by students, individual development of all students based on mastering universal learning activities. At the same time, a modern child is not only a member of a local community, group, association, not only a student of a class, school, a citizen of his country. In an open world, it has wide access to information, endless opportunities in communication, cognition, activity. The openness of the modern global world provides significant opportunities for self-organization of children in it. All this puts another pattern of self-organization - the unity of the limitations and infinity of self-organization of children in the global world.

In an open and accessible educational environment of a new type, each student can find their "teachers" and their "class". They can collect any set of "educational services" in their formalized (distance courses on structured, welldesigned and approved programs, various textbooks of reputable scientists and teachers, methodological developments, etc.) and informal (master class, training) options. As well as in spontaneously organized educational circles (participation in virtual projects, in communities) of social networks.

The student seeks the information he needs, acquires knowledge and builds his own system. He learns to interact with people of different ages, different languages, cultures and countries, becomes a participant in dialogue with the same students, communicator, seeks from the flow of information that is useful for enrichment own system of knowledge. Student learns to interact constructively with various experts, with representatives of various art cultures and the states.

Self-organized educational learning space is a way of organizing the educational process. Teachers encourage students to work together in independent group work to find an answer to the so-called "big question" through the Internet and other sources of information.

The basis of the self-organized musical art educational space contains the following creeds:

- self-organized music-theoretical or music-performance training arises at the initiative of students. They are motivated by choice and common interests with other students;

- the acquisition of musical knowledge and skills occurs in group work. Such training helps to develop memory and social skills;

- students form their own understanding of new creative ideas, linking it to what they know;

- students are able to understand more than teachers usually think, especially when they are in a comfortable, open environment. They are encouraged to experiment creatively and make mistakes in such environment;

- students are able to think critically and can learn quickly. The Internet helps them find answers to most music questions, and teacher encouragement and support builds confidence and resilience to acquire music performance skills on their own. Teachers have the opportunity not to interfere in the work of adolescents, but only offer them support and understanding.

Educational goals are achieved through students' joint search answer for the "big question", through the opportunity to know themselves, share thoughts and emotions. The "big question" ignites students' imagination and curios- 
ity. Such questions do not have an unambiguous answer. Their purpose is to encourage discussion and debate. They encourage children to come up with ideas, work together, use arguments and think critically, for example:

1. How can music change the world?

2. How is music created?

3. What does a piece of music contain?

4. Does a piece of music affect a person?

It is important that the teacher may not know the answer for the "big question". Such questions may not have a single clear answer at all. The task of the teacher is only to facilitate students' work, to create conditions for their self-organization. Yes, the teacher encourages students to form teams on their own, which they can change during the lesson, to look for answers for the "big question", to choose the form of presentation and to present their answers.

Facilitator (from the English to facilitate - to promote) - is a teacher whose main task is to stimulate, facilitate and guide the process of independent search for information and joint activities of students. Facilitation is the organization and management of the process of discussing certain issues or topics in a group of students, as it happens in the process of finding an answer for a "big question" in a self-organized educational space. At the same time, the "big question" is an important part of this space. As educational theorist Edward O. Wilson has pointed out, "the right answer to a trivial question is also trivial, but the right question, even if unresolved, is a guide to meaningful discovery".

Thus, the introduction of self-organized educational space is aimed at creating a safe micro-environment for students. Such space where children get a positive experience of learning music on their own. Stages (posing a "big question", researching its content) introduction of self-organized educational space contribute to the formation of the ability to distribute roles, bring the case to an end, regulate their own learning behavior and prove their own opinion, which is associated with students' independence [2].

Self-organized educational space creates an atmosphere of support and respect, encourages independent judgment of students and their academic achievements. At the same time, the independence of students is associated with the active work of thoughts, musical and aesthetic feelings. It is associated with students' will and actions and it develops the ability to present conclusions in the process of achieving successful implementation of decisions, overcoming difficulties. All these are necessary components of a self-organized educational space.

\section{Bibliography:}

1. Антонюк В. Українська вокальна школа : етнокультурологічний аспект : монографія. Київ : Українська ідея, 2001. 144 с.

2. Василенко О. Самоорганізований освітній простір - інновація в підготовці школярів для самостійності. Педагогіка формування особистості у вищій $i$ загальноосвітній школах. Харків, 2020. № 70. Т. 1.

3. Гнидь Б. Історія вокального мистецтва. Київ : НМАУ, 1997. 318 с.

4. Свтушенко Д. Роздуми про голос : нотатки педагога-вокаліста. Київ : Муз. Україна, 1979. 91 с.

5. Корецька Л., Носач І., Пєтушкова Л. Методичні рекомендації з використання методики "Самоорганізований освітній простір". Київ, 2019. 85 с.

6. Манжонс Л. Методика постановки голоса. Славянск : Печатный двор, 2003. Ч. 2. 116 с.

7. Морозов В. Педагогічний процес як предмет педагогічного дискурсу. Київ, 2013. Вип. 30. С. 35-41.

8. Панченко Г. Методи самоорганізації вокального навчання. Мелітополь : МДПУ, 2017. 78 с.

9. Печерських Т. Самоорганізований освітній простір - інноваційна методика соціального виховання особистості. Харків : ХНПУ ім. Г. Сковороди, 2019.

10. Прядко О. Методика розвитку співацького голосу у майбутніх педагогів-музикантів. Київ, 2009. 23 с.

11. Яо Ямін. Методика самоорганізації навчального простору майбутніх викладачів-музикантів у педагогічних університетах України. Київ, 2018.

\section{References:}

1. Antoniuk V. H. (2001) Ukrainska vokalna shkola : etnokulturolohichnyi aspekt : monohrafiia [Ukrainian vocal school : ethnocultural aspect : monograph]. K., Ukrainska ideia. 144s. [in Ukrainian]

2. Vasylenko O. M. (2020) Samoorhanizovanyi osvitnii prostir - innovatsiia v pidhotovtsi shkoliariv dl samostiinosti. Pedahohika formuvannia osobystosti u vyshchii i zahalnoosvitnii shkolakh [Self-organized educational space is an innovation in preparing students for independence. Pedagogy of personality formation in higher and general education schools]. Kharkiv. № 70, T. 1 . [in Ukrainian]

3. Hnyd B. P. (1997) Istoriia vokalnoho mystetstva [History of vocal art] K., NMAU. 318 s. [in Ukrainian]

4. Ievtushenko D. H. (1979) Rozdumy pro holos : notatky pedahoha-vokalista [Reflections on the voice: notes of the teacher-vocalist]. K., Muz. Ukraina. 91 s. [in Ukrainian]

5. Koretska L. V., Nosach I. V., Pietushkova L. A. (2019) Metodychni rekomendatsii z vykorystannia metodyky "Samoorhanizovanyi osvitnii prostir" [Methodical recommendations on the use of the method "Self-organized educational space"]. Kyiv, $85 \mathrm{~s}$. [in Ukrainian]

6. Manzhons L. (2003) Metodika postanovki golosa [Voice training technique]. Slavyansk : Pechatnyiy dvor. Ch. 2 . 116 s. [in Russian]

7. Morozov V. (2013) Pedahohichnyi protses yak predmet pedahohichnoho dyskursu [Pedagogical process as a subject of pedagogical discourse]. Kyiv. S. 35-41. [in Ukrainian]

8. Panchenko H. P. (2017) Metody samoorhanizatsii vokalnoho navchannia [Methods of self-organization of vocal training]. Melitopol, MDPU. 78 s. [in Ukrainian]

9. Pecherskykh T. P. (2019) Samoorhanizovanyi osvitnii prostir - innovatsiina metodyka sotsialnoho vykhovannia osobystosti [Selforganized educational space - an innovative method of social education of the individual]. Kharkiv, KhNPU im. H. Skovorody. [in Ukrainian] 
10. Priadko O. M. (2009) Metodyka rozvytku spivatskoho holosu u maibutnikh pedahohiv-muzykantiv [Methods of developing a singing voice in future music teachers]. Kyiv. $23 \mathrm{~s}$. [in Ukrainian]

11. Iao Yamin. (2018) Metodyka samoorhanizatsii navchalnoho prostoru maibutnikh vykladachiv-muzykantiv u pedahohichnykh universytetakh Ukrainy [Methods of self-organization of the educational space of future music teachers in pedagogical universities of Ukraine]. Kyiv. [in Ukrainian]

Бухнієва О. А., Банкул Л. Д. Особливості впровадження самоорганізованого освітнього простору навчання музичного мистецтва

Стаття присвячена розгляду створення самоорганізованого освітнього навчального простору галузі музичного мистецтва й особливостям його впровадження в сучасну систему освіти в навчальних закладах. Цей процес супроводжується суттєвими інноваційними змінами в педагогічній теорії і практиці, зокрема музичній. У статті зазначено, щео одним зі стратегічних напрямів у модернізащії освіти є перехід до нової освітньої парадигми, щцо забезпечує пізнавальну активність і самостійність мислення учнів. Підкреслено, шяо в умовах стрімкого розвитку иифрових освітніх технологій підвищилася увага до суб'єктів навчання, їхніх потреб, інтересів, здібностей, щзо потребує переосмислення організації навчального та виховного процесів, методів $і$ засобів, а також змісту освіти. Доведено інноваційність створення самоорганізованого освітнього навчального простору музичного мистецтва, y зв'язку із ичи відбувається переосмислення цілей, змісту і завдань навчання, а також оновлення питання підготовки майбутніх учителів музичного мистецтва. Встановлено, щя самоорганізаційний освітній навчальний простір дає можливість учням розширити власний кругозір, світогляд, покращити свою поведінку, навчає брати на себе відповідальність за групову роботу, виховувати в себе почуття уявного та морального дорослішення. Визначена роль вчителя-фасилітатора, який створює творчу сприятливу атмосферу підтримки роботи учнів. Доведено, що в результаті впровадження самоорганізованого освітнього навчального простору створюється безпечне для учнів мікросередовище, уякомуучні отримують позитивний досвід навчання музичного мистецтва. Визначено, щуо традиційна система навчання, поширена в більшості освітніх закладів, має обмежені можливості щодо саморозвитку, оскільки вона нормативна. Зміна даної системи - процес, щзо потребує великих ресурсних $і$ часових витрат. У відкритому освітньому просторі перехід від нормативного до відкритого самоорганізованого навчання дає можливість найбільш ефективного використання всієї повноти синергетичного підходу як основи становлення відкритих способів музичнопізнавальної діяльності, пошуку адекватних творчих методів і технологій музичної освіти.

Ключові слова: самоорганізований освітній простір, саморозвиток, відкритість системи освіти, фасилітатор, інноваційні зміни, музичне мистецтво. 